Article

\title{
Effects of Heavy Ion Particle Irradiation on Spore Germination of Bacillus spp. from Extremely Hot and Cold Environments
}

\author{
Vincenzo Zammuto ${ }^{1}{ }^{\oplus}$, Maria G. Rizzo ${ }^{1, *}$, Laura M. De Plano ${ }^{1}$, Domenico Franco ${ }^{1}{ }^{\circledR}$, \\ Salvatore Guglielmino ${ }^{1}$, Maria T. Caccamo ${ }^{2}{ }^{\circ}$, Salvatore Magazù ${ }^{2}$, Akira Fujimori ${ }^{3}$, \\ Angelina Lo Giudice ${ }^{4}\left(\mathbb{D}\right.$, Mauro Guglielmin ${ }^{5}$, Kevin Roderick McAlpin ${ }^{6,7}$, Ralf Moeller ${ }^{6,7}$ (1) \\ and Concetta Gugliandolo ${ }^{1}$ (1)
}

1 Department of Chemical, Biological, Pharmaceutical and Environmental Sciences, Research Centre for Extreme Environments and Extremophiles, University of Messina, V.le F. Stagno d'Alcontres 31, 98166 Messina, Italy; vzammuto@unime.it (V.Z.); ldeplano@unime.it (L.M.D.P.); dfranco@unime.it (D.F.); sguglielm@unime.it (S.G.); cgugliandolo@unime.it (C.G.)

2 Department of Mathematics, Computer Sciences, Physics and Earth Sciences, University of Messina, V.le F. Stagno d'Alcontres 31, 98166 Messina, Italy; mcaccamo@unime.it (M.T.C.); smagazu@unime.it (S.M.)

3 Department of Basic Medical Sciences for Radiation Damages, Molecular and Cellular Radiation Biology Group, NIRS/QST, Chiba 263-8555, Japan; fujimori.akira@qst.go.jp

4 Institute of Polar Sciences, National Research Council (CNR-ISP), Spianata San Raineri 86, 98122 Messina, Italy; angelina.logiudice@cnr.it

5 Department of Theoretical and Applied Sciences, University of Insubria, Via J.H. Dunant, 21100 Varese, Italy; mauro.guglielmin@uninsumbria.it

6 Institute of Aerospace Medicine, Radiation Biology Department, German Aerospace Center, Aerospace Microbiology, DLR, Linder Höhe, D-51147 Cologne/Köln, Germany; ralf.moeller@dlr.de (R.M.); kevin.mcalpin@dlr.de (K.R.M.)

7 Natural Sciences Department, University of Applied Sciences Bonn-Rhein-Sieg (BRSU), D-53359 Rheinbach, Germany

* Correspondence: mgrizzo@unime.it

Received: 13 October 2020; Accepted: 28 October 2020; Published: 30 October 2020

\begin{abstract}
Extremophiles are optimal models in experimentally addressing questions about the effects of cosmic radiation on biological systems. The resistance to high charge energy (HZE) particles, and helium (He) ions and iron (Fe) ions (LET at 2.2 and $200 \mathrm{keV} / \mu \mathrm{m}$, respectively, until $1000 \mathrm{~Gy}$ ), of spores from two thermophiles, Bacillus horneckiae SBP3 and Bacillus licheniformis T14, and two psychrotolerants, Bacillus sp. A34 and A43, was investigated. Spores survived He irradiation better, whereas they were more sensitive to Fe irradiation (until 500 Gy), with spores from thermophiles being more resistant to irradiations than psychrotolerants. The survived spores showed different germination kinetics, depending on the type/dose of irradiation and the germinant used. After exposure to He $1000 \mathrm{~Gy}$, D-glucose increased the lag time of thermophilic spores and induced germination of psychrotolerants, whereas L-alanine and L-valine increased the germination efficiency, except alanine for A43. FTIR spectra showed important modifications to the structural components of spores after Fe irradiation at $250 \mathrm{~Gy}$, which could explain the block in spore germination, whereas minor changes were observed after He radiation that could be related to the increased permeability of the inner membranes and alterations of receptor complex structures. Our results give new insights on HZE resistance of extremophiles that are useful in different contexts, including astrobiology.
\end{abstract}

Keywords: Bacillus; extremophiles; heavy ion particle (HZE) radiations; nutrient germinants; spore germination; spore resistance 


\section{Introduction}

The boundary conditions of life on Earth have been tested in different possible directions, encompassing the limits of temperature, $\mathrm{pH}$, pressure, salinity, nutrients, and radiations. A great variety of terrestrial environments exhibit extremes in one or more physical or chemical conditions. This is the case for both marine hydrothermal vents (shallow and deep-sea vents) and polar (Arctic and Antarctic) areas, where microbial (poly) extremophiles are generally the most abundant life forms [1-5]. Poly-extremophiles are important tools for research in different disciplines, spanning from adaptations to harsh conditions [6], with implications for both the origin of life on Earth [7] and the search for extra-terrestrial life [8,9], to novel strategies to avoid or mitigate contamination for either industrial processes or the astrobiology field $[10,11]$. Exploring microbial diversity in extreme environments and understanding their adaptive mechanisms allows us to expand our knowledge of potentially habitable environments capable of supporting extraterrestrial life in various planetary bodies within the Solar System, including Mars, Venus, and the satellites of Jupiter (Io, Europa, Ganymede, and Callisto) and Saturn (Titan and Enceladus) [12-16]. Several studies have reported the survival and growth of microorganisms under laboratory-simulated extraterrestrial environments, such as under Enceladus-like and Mars-like conditions [11,17,18].

Resistance to high doses of radiation has been observed in several members of the domains Bacteria and Archaea [19]. Organisms resistant to different types of ionizing radiation (IR; such as X-rays, gamma rays, and charged particles) have been isolated from a number of environments [20], including the radiation resistant thermophile Deinococcus geothermalis [21] and the hyperthermophiles Pyrococcus furiosus [22], Thermococcus gammatolerans EJ [23], and Thermococcus radiotolerans [24], which all provided new insights into the field of radiation microbiology.

Members of the Bacillus genus are able to produce spores that represent dormant forms that are resistant to several environmental and laboratory stresses, including sterilization techniques such as chemical oxidizing agents, extreme desiccation, wet and dry heat, ultraviolet radiation, and gamma irradiation [25]. Therefore, spores have been acknowledged as the hardiest known form of life on Earth [18]. Bacilli thriving in multi-extreme environmental conditions have been reported to possess high and unexplored resistance to stresses [4,5]. Several novel thermophilic Bacillus and Geobacillus strains were isolated from shallow hydrothermal vents (SHV) off the Eolian Islands (Italy) and investigated for their potential biotechnological applications [26-29]. Recently, the spore resistance to artificial and environmental stressors of Bacillus horneckiae SBP3 DSM 103063 and Bacillus oceanisediminis APA DSM 103062, isolated from two vents off Panarea Island (among the Eolian Islands), has been compared to that of Bacillus spp. (Bacillus horneckiae DSM 23495, Bacillus pumilus SAFR-032, and Bacillus nealsonii DSM 15077) isolated from spacecraft assembly facilities, and of Bacillus subtilis 168, the biodosimetry strain and space microbiology model organism [30]. Interestingly, spores from SBP3 showed a high level of resistance to stresses that they have never naturally encountered before, such as UV-C, X-rays, hydrogen peroxide, dry heat, and space vacuum. In comparison with B. subtilis 168 , SBP3 spores were significantly more resistant to low-pressure argon plasma, $\mathrm{H}_{2} \mathrm{O}_{2}$, and dry and wet heat [30]. Furthermore, the UV-C and the thermal resistance of spores of Bacillus licheniformis T14, isolated from a vent off Panarea Island [28], were also reported under wet heat and dry heat conditions [31,32]. Poly-resistant psychrotolerant Bacillus strains, isolated from the active layer in a continuous permafrost area at Edmonson Point (Antarctica) (namely, A30, A34, A43, A45, B51, and B58), were screened for their resistance to several stresses. Spores of A34 and A43 were reported to possess a high degree of resistance to UV-C [31]. Altogether, these results suggested that spores are not necessarily radiation-resistant, but the mechanisms involved with protecting themselves in hot and cold environments could also be involved in resisting the effects of UV-C radiation. Moreover, strains belonging to the same genus or species responded differently to UV-C radiation, which may reflect the adaptation of the studied strains to their own harsh environmental conditions. Thus, isolates from Eolian SHV and Antarctic permafrost active-layer could represent a richer source of poly-resistant bacteria than their mesophilic, terrestrial counterparts. 
Survival of bacilli species depends on the ability of dormant spores to grow and multiply under favorable environmental or nutritional conditions. It is known that spore populations vary in the degree of dormancy, with some spores being more dormant than others [33]. Germination can be induced by different types of agents, such as high pressures [34]; temperatures; salinity stresses [35,36]; and nutrient germinants including amino acids, sugars, or purine nucleosides. These agents are involved in a sequence of events that result in a breakdown of the spore structure and the loss of their resistant properties. L alanine, L-asparagine, and L-valine are examples of nutrient germinants binding in a stereospecific manner to spore-specific protein complexes in the inner membrane, termed germinant receptors, and are reported to trigger germination in B. subtilis [37]. Consequently, the germination process is relevant for scientific investigations (such as in food contamination and disease pathogenesis) to prevent spore germination or to accelerate it and then kill the newly sensitive germinated spores.

One of the main astrobiological goals is the devotion to understanding the limit of microbial resistance to extraterrestrial conditions, with much attention being paid to cosmic radiation as the environmental space parameter that may prevent the preservation and spread of life outside the Earth. The exposure to ionizing radiations, which represent a major part of the cosmic radiation spectrum, can cause cellular damages directly by affecting biomolecules or indirectly by causing radiolysis of water to reactive oxygen species (hydroxyl radicals, superoxide, and hydrogen peroxide) involved in severe oxidative stress to all cellular macromolecules [38]. High (H) Charge (Z) Energy (E) (HZE) particles make up about $1 \%$ of the galactic cosmic radiation spectrum and they can reach very high energies, up to $1000 \mathrm{GeV}[39,40]$. Due to their high ionization energy and great penetration depth, the HZE particles represent one of the main hazardous components of space for any biological system staying for extended periods of time [10,41]. The biological effects of IR are related to the linear energy transfer (LET), the value indicating the local energies transferred by one particle, usually expressed in $\mathrm{keV} / \mu \mathrm{m}$, which is related to a particle's charge and velocity (energy per nucleon) and the elemental composition of the traversing medium. Therefore, HZE particles' effects on biological samples depend on their LET values [42-44].

In recent times, the STARLIFE international campaign has aimed to study the effects of IR, including those caused by HZE particles in astrobiological model systems, such as spores of B. subtilis 168 [45]. Several studies on the survival of $B$. subtilis to high-energy charged particles have reported that the spore's structural components (i.e., $\alpha / \beta$-type small acid soluble spore proteins, core water content, and dipicolinic acid) play an important role in spore resistance, mainly depending on the ability to repair and protect DNA [46-48]. Moreover, spore survival depended on the LET of the applied species of ions and radiation, whereas the exposure to HZE particles, for example iron ions (200 keV/ $\mu \mathrm{m}$, high-LET radiation), led to a low level of spore survival compared to low-energy charged particles, such as helium $(2.2 \mathrm{keV} / \mu \mathrm{m})$ [14]. However, there are no studies evaluating the effects of HZE particles on spores from poly-extremophilic bacilli, which may have a different resistant mechanism due to the structural spore's components, nor on the germination process after HZE exposure.

In this study, the resistance to HZE was investigated on spores from B. horneckiae SBP3 and B. licheniformis T14, isolated from Eolian shallow hydrothermal vents, and two Bacillus sp. strains A34 and A43 from the Antarctic permafrost active layer, as these strains are highly resistant to environmental and artificial stressors, including non-ionizing radiation (i.e., UV-C). In the frame of the STARLIFE program, we irradiated spores with accelerated heavy ions of helium $(\mathrm{He})$ and iron (Fe) at LET of 2.2 and $200 \mathrm{keV} / \mu \mathrm{m}$, respectively. The effects related to irradiation with ion species of $\mathrm{He}$ and Fe on structural components of spores from thermophilic and psychrotolerant strains were investigated using a spectroscopic FTIR technique. The roles of D-glucose, L-alanine, and L-valine as germinant agents were evaluated in the germination process of spores surviving irradiation. 


\section{Materials and Methods}

\subsection{Sampling Areas}

Shallow hydrothermal vents (SHV) of the Eolian Islands (Italy) are characterized by unusual field conditions (high temperature and salinity, low $\mathrm{pH}$ values, high concentrations of $\mathrm{H}_{2} \mathrm{~S}$, hydrocarbons, heavy metals, etc.) prohibitive for most organisms [27].

In extremely cold environments, such as those at Edmonson Point on the eastern slope at the foot of Mount Melbourne (Northern Victoria Land), the soils are affected by permafrost, and in their upper part (called the active layer), the microorganisms are able to survive prolonged subzero temperatures (at least 340 days per year); strong fluctuations of temperature, water, and nutrients; and long-term background radiation exposure [49].

\subsection{Bacterial Strains and Spore Purification}

Bacillus strains used in this study are listed in Table 1, together with their optimal growth temperatures and spore resistance to UV-C, expressed as the lethal dose required to kill $90 \%$ of the spore population (LD90). Two thermophilic strains, Bacillus horneckiae SBP3 [30] and Bacillus licheniformis T14 [28] were isolated from samples collected in June 2006 in the immediate vicinity of two shallow submarine hydrothermal vents off Panarea Island (Eolian Islands, Italy), named Black Point (coordinates:

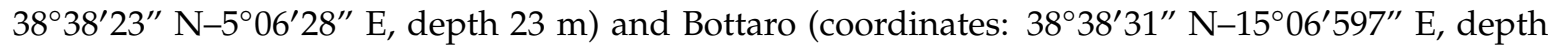
$8 \mathrm{~m}$ ). Thermophilic isolates were routinely maintained on tryptone soy agar (TSB; Oxoid, Milan, Italy) supplemented with $1 \% \mathrm{NaCl}$ (TSA1).

Table 1. Bacillus species used in this study, their optimal temperature for growth $\left({ }^{\circ} \mathrm{C}\right)$, and their spore resistance $\left(\mathrm{LD}_{90}\right)$ to UV-C $(254 \mathrm{~nm})$.

\begin{tabular}{|c|c|c|c|c|}
\hline Strain & Source & $\begin{array}{c}\text { Optimal } \\
\text { Temperature for } \\
\text { Growth }\left({ }^{\circ} \mathrm{C}\right)\end{array}$ & $\begin{array}{l}\text { Spore Resistance } \\
\text { to UV-C }\left(\mathrm{LD}_{90}\right)\end{array}$ & Reference \\
\hline Bacillus horneckiae SBP3 & $\begin{array}{l}\text { Black point, shallow hydrothermal } \\
\text { vent (Panarea Island, Italy) }\end{array}$ & 45 & $139 \pm 15$ & [30] \\
\hline Bacillus licheniformis T14 & $\begin{array}{l}\text { Bottaro, shallow hydrothermal } \\
\text { vent (Panarea Island, Italy) }\end{array}$ & 50 & $127 \pm 13$ & [31] \\
\hline Bacillus sp. A34 & Antarctic soil (Edmonson point) & 15 & $127 \pm 10$ & [31] \\
\hline Bacillus sp. A43 & Antarctic soil (Edmonson point) & 15 & $110 \pm 10$ & [31] \\
\hline
\end{tabular}

Two psychrotolerant strains, Bacillus sp. A34 and A43, were isolated in January 2014 from the Antarctic permafrost active layer at Edmonson Point (coordinates: 74 $19^{\prime} 44.2^{\prime \prime}$ S-165 07'59.7' E, Northern Victoria Land, Antarctica) [49]. Bacillus sp. A34 and A43 belong to the Italian Collection of Antarctic Bacteria of the National Antarctic Museum (CIBAN-MNA).

For long term storage, we kept the strains frozen in nutrient broth (Oxoid) at $-80{ }^{\circ} \mathrm{C}$ with the addition of $50 \%(\mathrm{v} / \mathrm{v})$ glycerol.

Sporulation of bacterial isolates was induced in the agarized Schaeffer's Sporulation Medium (containing $0.1 \% \mathrm{KCl}, 0.012 \% \mathrm{MgCl}_{2}, 0.5 \mathrm{mM} \mathrm{CaCl}_{2}, 0.01 \mathrm{mM} \mathrm{MnCl} 2,0.001 \mathrm{mM} \mathrm{FeSO}$, and $1.5 \%$ agar) [50]. Overnight cultures in tryptone soy broth (TSB; Oxoid, Milan, Italy) with the addition of $1 \%$ $\mathrm{NaCl}$ (TSB1) $(200 \mu \mathrm{L})$ were inoculated by spreading onto the medium, and plates were incubated at each strain's optimal temperature for 5 days. Spore preparations were checked to be free of vegetative cells and to consist of $>99 \%$ spores by phase-contrast microscopy. Harvested spores were washed 10 times and resuspended in sterile distilled water before storage at $4^{\circ} \mathrm{C}$.

\subsection{Radiation Exposition to HZE}

Preparation of spores for exposure to heavy ion particles was performed as described previously [46]. Briefly, suspensions of spores of the different Bacillus strains were prepared in sterile distilled water to a final concentration of $10^{8}$ spores $/ \mathrm{mL}$. Triplicate samples of spore suspensions 
$(100 \mu \mathrm{L})$ were individually exposed, between 0 to $8 \mathrm{~h}$, to two different types of high-energy-charged ions: $\mathrm{He}$, with energy of $150 \mathrm{MeV} /$ nucleon $(\mathrm{LET}=2.2 \mathrm{keV} / \mu \mathrm{m}$ ), and $\mathrm{Fe}$, with energy of $500 \mathrm{MeV} /$ nucleon $(\mathrm{LET}=200 \mathrm{keV} / \mu \mathrm{m})($ Table 2$)$.

Table 2. Radiation used in STARLIFE experiments.

\begin{tabular}{cccc}
\hline Ion & $\begin{array}{c}\text { Energy } \\
\mathbf{( M e V / n )}\end{array}$ & $\begin{array}{c}\text { LET } \\
\mathbf{( k e V / \mu m )}\end{array}$ & $\begin{array}{c}\text { Intensity } \\
\mathbf{( P a r t i c l e s / s )}\end{array}$ \\
\hline Helium (He) & 150 & 2.2 & $2.0 \times 10^{9}$ \\
Iron (Fe) & 500 & 200 & $2.5 \times 10^{8}$ \\
\hline
\end{tabular}

Irradiations were performed at the heavy ion medical accelerator (HIMAC) facility of the National Institute for Radiological Sciences (NIRS) in Chiba, Japan. The irradiation geometry of the HIMAC and dose calculations have been described [51].

\subsection{Spore Survival}

Spore survival was evaluated from appropriate dilutions in distilled water as the ability to form colonies and was expressed as colony forming units (CFU/mL). Aliquots of each sample were inoculated onto plates of TSA1. Plates were incubated at each strain's optimal temperature for growth, for 24 or $48 \mathrm{~h}$ for thermophilic and psychrophilic strains, respectively. The surviving fraction of spores was determined from the quotient $\mathrm{N} / \mathrm{N}_{0}$, where $\mathrm{N}$ is the number of $\mathrm{CFU} / \mathrm{mL}$ of the irradiated spores and $\mathrm{N}_{0}$ represents the CFUs of the non-treated spores. Survival curves were obtained by plotting the logarithm of $\mathrm{N} / \mathrm{N}_{0}$ as a function of the treatments. Spore inactivation curves were obtained as described previously [51]. Each experiment was repeated three times and the data are expressed as averages \pm standard deviations.

In order to compare the resistance of spores from the tested strains with that of B. subtilis 168, we elaborated data as $\mathrm{D}_{37}$ values, the dose of ionizing radiation required to kill $63 \%$ of the initial spore population, determined from the linear portion of the semi-logarithmic curve [46].

The significant differences in the survival rates were determined by analysis of variance (ANOVA) and differences with $p \leq 0.05$ were considered statistically significant.

\subsection{Spectroscopic Analysis}

Fourier transform infrared (FTIR) spectroscopy was used to identify functional groups, such as carboxyl, phosphate, and amine groups, through their characteristic absorption bands in defined regions of the spectrum [52,53].

The aliquots of spore suspension $(20 \mu \mathrm{L})$ of non-irradiated $\left(1 \times 10^{8} \mathrm{CFU} / \mathrm{mL}\right)$ and irradiated spores were dried in sterile slides at room temperature and then analyzed. Conformational changes in proteins and internal vibrational modes of non-irradiated, He-irradiated, and Fe-irradiated spores were determined by FTIR microscope LUMOS. The spectrometer allowed for the collection of spectral data at $4 \mathrm{~cm}^{-1}$ resolution over 128 scans in the $400-4000 \mathrm{~cm}^{-1}$ spectral range. To compare the spectra, we normalized them as described previously [53].

\subsection{Germination Assay}

Germination conditions of non-irradiated and He/Fe-irradiated spores were evaluated in the presence of germinant agents D-glucose (Glu), L-alanine (Ala), and L-valine (Val). The germination assay was carried out in 96-well microplates. Germination medium contained $25 \mathrm{mM}$ 4-(2-hydroxyethyl)-1-piperazineethanesulfonic acid (HEPES) buffer (Sigma-Aldrich) (pH 7.4) and $50 \mathrm{mM}$ of each germinant agent. D-glucose (Glu), L-alanine (Ala), and L-valine (Val) were separately dissolved in Milli-Q and filter sterilized through a $0.22 \mu \mathrm{m}$ pore-size membrane. Wells were filled with $180 \mu \mathrm{L}$ of germination medium. Each spore suspension in HEPES buffer was added $(20 \mu \mathrm{L})$ into 
wells, in 4 replicates, with $\mathrm{OD}_{600 \mathrm{~nm}}=0.2$. The microplates were incubated at the optimal growth temperature for each strain in a multiplate reader (Thermo Scientific Multiskan GO) and germination was monitored by reading the drop of absorbance at regular intervals $(2 \mathrm{~min})$ for $120 \mathrm{~min}$. Microplates were shaken for $5 \mathrm{~s}$ prior to each reading.

During germination, the dormant spores lose their refractivity to phase-contrast microscopy. The refractivity loss was quantified spectrophotometrically by measuring the optical density of the germination culture at $600 \mathrm{~nm}\left(\mathrm{OD}_{600 \mathrm{~nm}}\right)$ [50]. All $\mathrm{OD}_{600 \mathrm{~nm}}$ data were normalized to the starting $\mathrm{OD}_{600 \mathrm{~nm}}$ - the $\mathrm{OD}_{600 \mathrm{~nm}}$ at each measured time point was dived by the first reading $\left(t_{0} \mathrm{~min}\right)$, yielding the relative $\mathrm{OD}_{600 \mathrm{~nm}}$, given as a percentage $\left(\% \mathrm{OD}_{600 \mathrm{~nm}}\right)$. An approximately $60 \%$ decrease in the relative $\mathrm{OD}_{600 \mathrm{~nm}}$ indicates that all spores in the germination culture have germinated successfully [35]. The lag-time $(\mathrm{min})$, representing the first time-point of the linear part of the decrease in relative $\mathrm{OD}_{600 \mathrm{~nm}}$, indicates the duration of the phase before the majority of spores lose their refractivity.

The significance of differences in the germination process was determined by analysis of variance (ANOVA), and differences with $p$-values of $\leq 0.01$ or $p$-values $\leq 0.05$ were considered statistically significant.

\section{Results}

\subsection{Spores Survival}

Survival curves of tested spores from Bacillus spp. strains irradiated with He and Fe particles are reported in Figure 1. Each strain's spore viability, following HZE treatments, showed a decrease in viable spore numbers $\left(\mathrm{N} / \mathrm{N}_{0}\right.$, where $\mathrm{N}$ is the number of $\mathrm{CFU} / \mathrm{mL}$ of the irradiated spores and $\mathrm{N}_{0}$ represents the CFUs of the non-treated spores) with increasing doses of $\mathrm{He}$ and Fe beams (Figure 1).


Figure 1. Survival curves of spores from the different tested Bacillus spp. to radiations of (A) helium ions and (B) iron ions.

After exposure to He, inactivation kinetic curves of spores from psychrotolerants exhibited an exponential shape, whereas those from thermophiles showed a sigmoidal shape (Figure 1A). Spores were resistant to He irradiation until $1000 \mathrm{~Gy}$, with thermophiles SBP3 and T14 being more resistant $\left(\mathrm{LD}_{90}=404 \pm 12\right.$ and $386 \pm 18 \mathrm{~Gy}$, respectively) than psychrotolerants $\mathrm{A} 34$ and $\mathrm{A} 43\left(\mathrm{LD}_{90}=332 \pm 15\right.$ and $346 \pm 12 \mathrm{~Gy}$, respectively); the thermophilic SBP3 strain showed the most robust spore resistance to irradiation with He ions (Figure 1A). The psychrotolerant A34 and A43 strains had the greatest loss of spore viability (about four orders of magnitude). 
All spores were shown to survive Fe irradiation until to $250 \mathrm{~Gy}$, whereas at $500 \mathrm{~Gy}$, the spore's viability from all strains was reduced fivefold, with the only exception being the T14 spores $\left(\mathrm{LD}_{90}=339\right.$ $\pm 21 \mathrm{~Gy}$ ), for which viability was reduced threefold (Figure 1B).

\subsection{Spectroscopic Analysis}

FTIR analysis was used to determine structural and biochemical changes occurring in spores from bacilli after exposure to He and Fe irradiations in comparison with untreated spores. The peak wavenumbers were assigned according to Vongsvivut et al. [54] Table 3.

Table 3. FTIR band assignments for the functional groups.

\begin{tabular}{ccc}
$\begin{array}{c}\text { Wavenumber Values } \\
\left(\mathbf{c m}^{-\mathbf{1}} \mathbf{)}\right.\end{array}$ & Band Assignment & References \\
$3300-3200$ & $\begin{array}{c}\text { H-bond and OH group of alcohol, phenols, } \\
\text { and organic acid including nucleic acids and proteins } \\
\text { amide A }\end{array}$ & {$[55]$} \\
$3100-3000$ & $\mathrm{n}(\mathrm{C}-\mathrm{H})$ of cis $\mathrm{C}=\mathrm{H}$ bonds & {$[56]$} \\
$\approx 2925$ & $(\mathrm{C}-\mathrm{H})$ from methylene $(-\mathrm{CH})$ group of lipids & {$[56]$} \\
$1700-1750$ & Protein and esters of muramic acid and ester fatty & {$[56]$} \\
$1660-1628$ & acid group & {$[57]$} \\
1548 & Amide I peptidic conformation & {$[58]$} \\
$\approx 1380$ & Amide II peptidic conformation & {$[59]$} \\
$\approx 1310$ & $\mathrm{CH}$ and CH $\mathrm{H}_{3}$ bending from lipids, DPA & {$[60]$} \\
$\approx 1066$ & amide III & {$[56]$} \\
$\approx 966$ & $(\mathrm{R}-\mathrm{O}-\mathrm{P}-\mathrm{O}-\mathrm{R})$ from ring vibrations of carbohydrates & {$[61]$} \\
$\approx 780$ & $(\mathrm{CH})$ of conjugated trans, trans isomers & {$[62]$} \\
\hline
\end{tabular}

Spectra of spores from bacilli display all the characteristic regions associated with amide A, amide I, amide II, dipicolinic acid (DPA), carbohydrates, and nucleic acids peaks. The structural similarity and differences between the examined regions can be seen qualitatively in the spectra reported in Figure 2.

Non-irradiated spores from thermophilic and psychrotolerant strains showed major differences in the regions $\cong 780-1200 \mathrm{~cm}^{-1}$ (attributed to nucleic acids and carbohydrates), and 1660-1628 $\mathrm{cm}^{-1}$ (amide I) and near $1548 \mathrm{~cm}^{-1}$ band (amide II), attributed to amino acids and polypeptides, whereas they were more similar in the region $3200-3300 \mathrm{~cm}^{-1}$ (amide A). Differences between the spectra of thermophiles, as well as between those of psychrotolerants, were observed mainly in the $800-1200 \mathrm{~cm}^{-1}$ region attributed to carbohydrates.

Irradiations with He $250 \mathrm{~Gy}$ and He 1000 Gy induced shifts and changes in the spectra in a dose-dependent manner (Figure 2). Overall, after He ion irradiations, qualitative changes in the spectra were observed in the $3200-3300 \mathrm{~cm}^{-1}$ region, attributed to amide A, with the highest variations observed in the spectrum of A43, and the lowest in T14. In the spectra of irradiated A34 and A43 spores, the peaks resulting in the $2100-2300 \mathrm{~cm}^{-1}$ region changed, and their intensity increased, indicating the degradation of lipids with the formation of $\mathrm{CO}_{2}$ and $\mathrm{CO}$ [63]. The region 1300-1400 $\mathrm{cm}^{-1}$, including dipicolinic acid (DPA) peaks, was shown to be reduced in intensity and modified after irradiation with He 1000 Gy and Fe 250 Gy in all strains.

We observed the major effects in the spectrum of A43 after He ion irradiation at $1000 \mathrm{~Gy}$, with evident shifts of peaks in the amide I and II region and in the $\cong 780 \mathrm{~cm}^{-1}$ band (attributed to nucleic acids). At the highest dose of He irradiation, we observed evident shifts and changes in the SBP3, T14, and A43 spectra in the region referred to carbohydrates.

After Fe ion irradiation, changes of peaks in SBP3, A34, and A43 spectra were observed in all the regions and referred to as amide I, amide II, DPA, amide A and nucleic acids, lipids, and carbohydrates $\left(800-1200 \mathrm{~cm}^{-1}\right.$ ), whereas the T14 spore spectrum showed minor variations (Figure 2). Modifications induced by Fe $250 \mathrm{~Gy}$ irradiation were similar to those observed after exposure to He $1000 \mathrm{~Gy}$. 


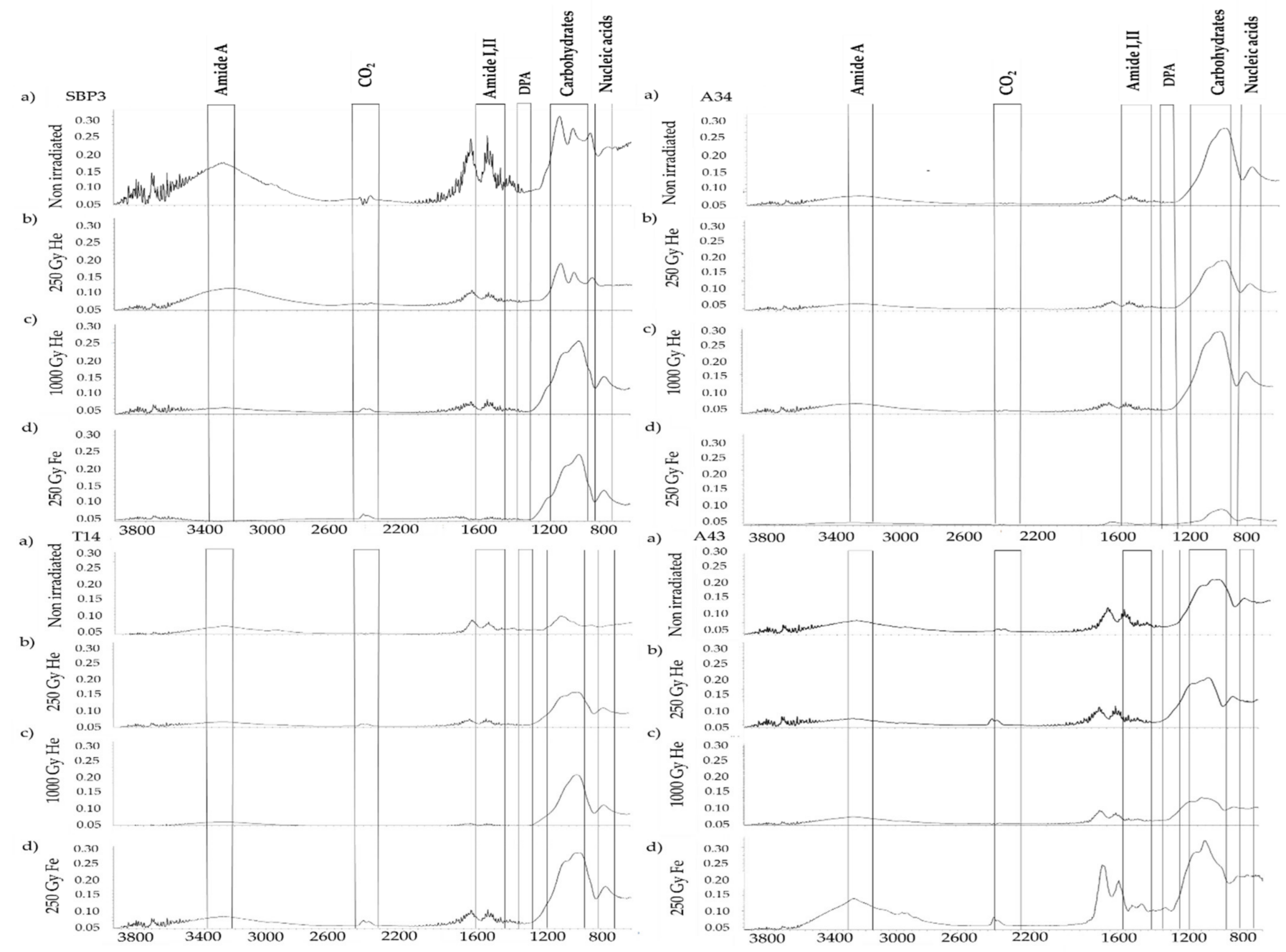

Figure 2. FTIR spectra of spores from Bacillus horneckiae SBP3, Bacillus licheniformis T14, Bacillus sp. A34, and Bacillus sp. A43 non-irradiated (a) and irradiated with He 250 Gy (b), He 1000 Gy (c), and Fe 250 Gy (d). 


\subsection{Germination Assay}

The germination monitoring of non-irradiated and $\mathrm{He} / \mathrm{Fe}$ ion-irradiated spores by measurement of relative absorbance $\left(\% \mathrm{OD}_{600 \mathrm{~nm}}\right)$ at regular intervals $(2 \mathrm{~min})$ for $120 \mathrm{~min}$ of exposure at each germinant are reported in Figures 3 and 4. The initial loss of absorbance (lag-time) and the germination efficiency, expressed as the relative absorbance after $120 \mathrm{~min}\left(\% \mathrm{OD}_{600 \mathrm{~nm}}\right)$ in the presence of the different germinant agents as trigger compounds, are reported in Table S1. Overall, germination efficiency varied from $\approx 1$ to $64 \%$ within $120 \mathrm{~min}$ after the addition of the germinant (Table S1). The ability of spores to germinate was stated as high if the efficiency was $30 \%$ or more, and as poor if the efficiency was $10 \%$ or less.

Non-irradiated spores from thermophilic strains germinated in the presence of D- glucose or L-valine as a single germinant compound (Figure 3). Differently from SBP3, spores from T14 were also able to germinate in the presence of L-alanine (Figure 3). A34 spores did not exhibit germination ability with all the germinants tested, whereas A43 spores germinated only with L-alanine (Figure 3). Germination efficiency of non-irradiated spores in the presence of the three used germinants was higher in the thermophilic SBP3 and T14 strains than in the psychrotolerant A34 and A43 spores (efficiency $<30 \%$ ) (Table S1, Figures 3 and 4).

He irradiation differently affected spore germination at different extents, depending on the dose of irradiation. After He irradiation at $250 \mathrm{~Gy}$, in the presence of D-glucose, the lag-time of thermophiles increased, and therefore germination was much slower than in non-treated spores (Table S1, Figure 3). Interestingly, germination of psychrotolerant A34 and A43 spores was induced with D-glucose after He expositions at $250 \mathrm{~Gy}$ (Figure 3). In the presence of amino acids, the lag-time of all spores was shorter, with the only exception being L-alanine for A43 spores (Table S1). After exposure to the maximum dose of irradiation with He ions (1000 Gy), all spores germinated slower with D-glucose than spores irradiated at $250 \mathrm{~Gy}$ dose (Figure 3). In the presence of alanine, germination enhanced in the respect of both non-irradiated and irradiated spores at He $250 \mathrm{~Gy}$, with the only exception being spores from A43, which were blocked in germination. In presence of L-valine, all spores exhibited an increased germination, including spores from A43. In general, germination efficiency greatly increased after exposure to He $1000 \mathrm{~Gy}$, with SBP3 and T14 being more efficient (34-64\% loss of $\mathrm{OD}_{600 \mathrm{~nm}}$ ) than A34 and A43 (5-47\% decrease $\left.\mathrm{OD}_{600 \mathrm{~nm}}\right)$ (Table S1).

Irradiation with Fe $250 \mathrm{~Gy}$ inhibited the germination of all spores despite the spores being viable (Figure 1) in the presence of all the trigger agents (Figure 4), indicating a block in spore germination. 

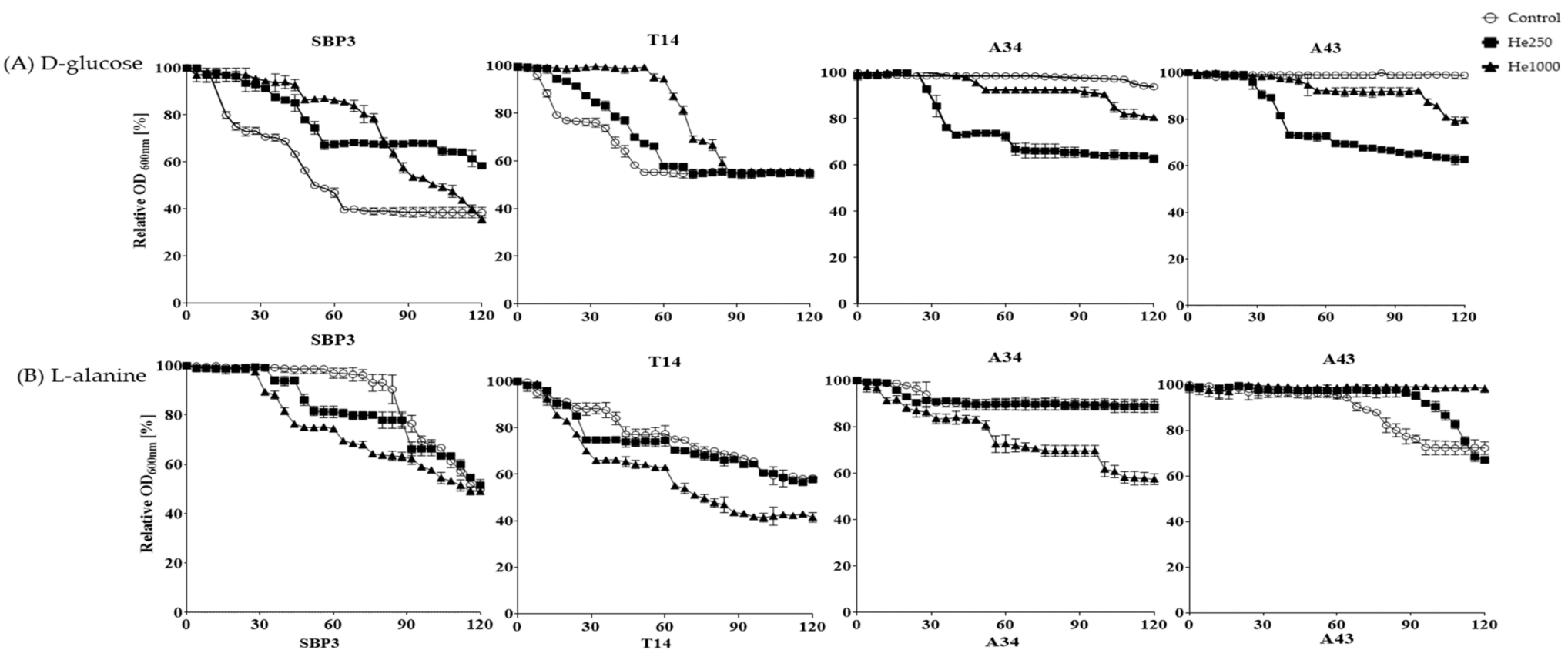

(C) L-valine
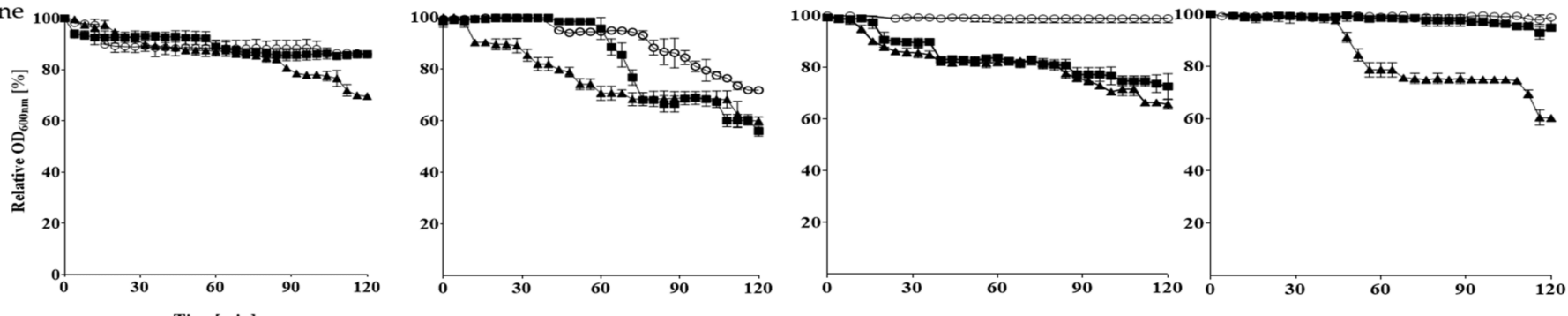

Figure 3. Germination curves of spores non-irradiated (white circles) and irradiated with He $250 \mathrm{~Gy}$ (black squares) and He $1000 \mathrm{~Gy}$ (black triangles) in the presence of the germinant agents: (a) D-glucose, (b) L-alanine, and (c) L-valine. Germination was monitored as relative absorbance percentage $\left(\mathrm{OD}_{600 \mathrm{~nm}} \%\right)$ at regular intervals $(2 \mathrm{~min}$ ) for $120 \mathrm{~min}$ of exposure to $50 \mathrm{mM}$ germinant compound. 
(A) D-glucose

SBP3

T14

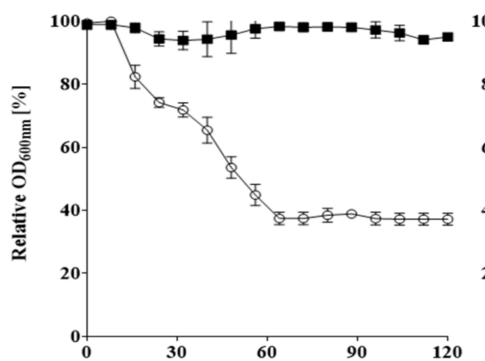

(B) L-alanine

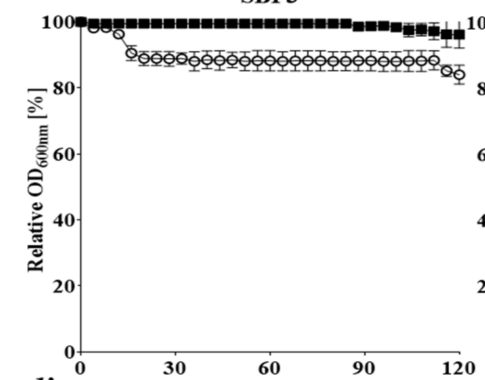

$\begin{array}{ccc}\text { (C) L-valine } & 30 & 60 \\ & & \text { SBP3 }\end{array}$

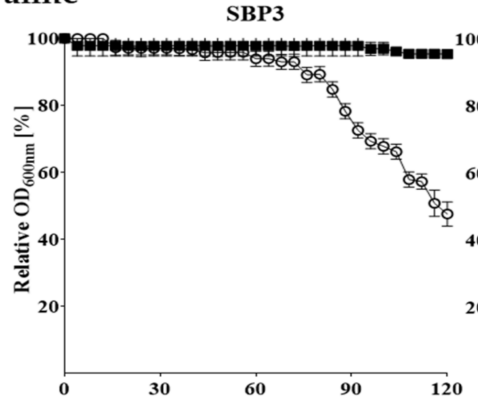

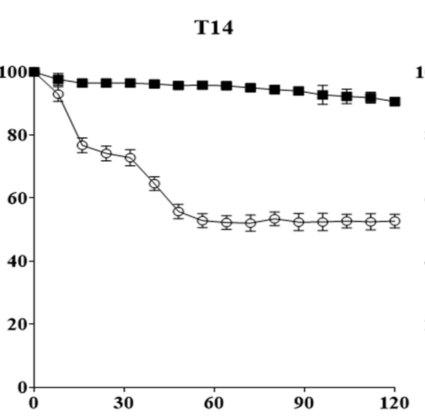

120


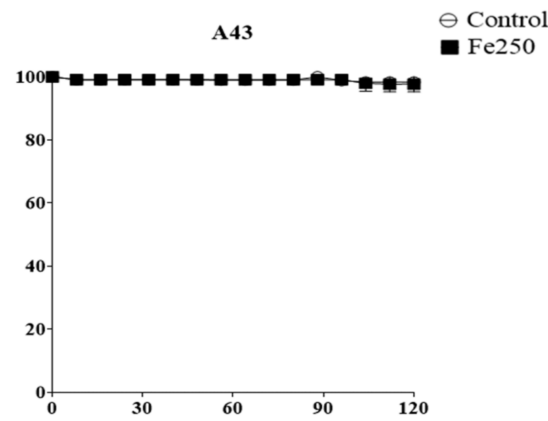

A43



A43

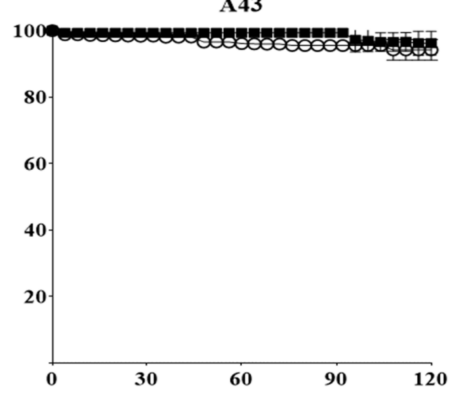

Figure 4. Germination curves of spores non-irradiated (white circles) and irradiated with Fe 250 Gy (black squares) in the presence of the germinant agents: (a) D-glucose, (b) L-alanine, and (c) L-valine. Germination was monitored as relative absorbance percentage $\left(\mathrm{OD}_{600 \mathrm{~nm}} \%\right)$ at regular intervals (2 min) for $120 \mathrm{~min}$ of exposure to $50 \mathrm{mM}$ germinant compound. 


\section{Discussion}

High-energy charged particles (HZE), such as protons, neutrons, electrons, and heavy ions, constitute a relevant part of IR by the Sun and galactic sources, or are trapped in the radiation belts of origin. The majority of ionizing radiation particles in space, about $87 \%$, is represented by protons [64]. All planets and celestial bodies are struck by protons and high-charge/high-energy ions, whereas some planets, including the Earth, possess a magnetosphere that traps the majority of ionizing particles. The ice moons Europa and Enceladus possess a magnetosphere from the nearby planets Jupiter and Saturn, respectively, but the impact of the HZE particles that do reach their ice surface produces free radical species that could kill dormant microorganisms [65]. However, environments associated with submarine hydrothermal systems on Earth have recently been observed in Europa and could allow for the development of life under the surface, where the radiation levels are lower [66]. Biological effects of HZE may affect biodiversity since surface radiation contributes to mutagenesis rates, including replication errors and DNA damage from UV, chemical oxidants, and desiccation $[67,68]$. Deposited energy excites electrons within biomolecules and induces direct damage, whereas the indirect mechanisms of radiation damage are linked to ionization or radiolysis of water, which composes $70-90 \%$ of vegetative cells' weight and $20-40 \%$ of bacterial spores' weight [18]. Water irradiated with IR results in the production of hydrated free electrons and highly reactive oxygen species with unpaired electrons, as well as free radicals, such as $\mathrm{H}$ and $\mathrm{OH}$, or their recombination products, such as hydrogen peroxide [69]. These radiogenic products are freely diffusible and migrate from their site of production toward oxidize biomolecules such as DNA and proteins. The presence of oxygen dissolved in irradiated water increases the production of hydrogen peroxide and the hydroxyl radical, and consequently, the indirect damages of macromolecules are greater [70]. The potential damages of the low linear energy transfer (LET) radiation can be attributed to ionization and excitation processes or to the interactions with reactive oxygen species (ROS) [71,72]. ROS could destroy or damage spore coats, core membranes, and/or essential germination receptors, leading to a blockage in spore germination and outgrowth $[25,73,74]$. Spores of Bacillus subtilis are widely studied for their ability to withstand desiccation and low temperature, and therefore they have been used as a model because it is foreseen that even more radiation-resistant bacteria could exist in the subsurface oceans of the icy moons Europa and Enceladus [75]. It is known that spore-protective strategies include (i) the production of two thick and highly cross-linked proteinaceous spore-coat layers [76], (ii) the production and deposition of a melanin-like UV-protective pigment in the spore-coat layer [77], (iii) the dehydration of the spore core via an unknown mechanism involving the spore-cortex protein DacB [78], (iv) the production and storage of large quantities of the calcium chelate of dipicolinic acid (Ca-DPA) in the spore core $[79,80]$, and (v) saturation of spore DNA with $\alpha / \beta$-type small acid soluble proteins (SASP) $[18,25,81]$. Structural differences in the integuments (exosporium, external coat, coat, and inner membrane) could be important in the resistance to HZE exposure of spores [82]. These layers differ among the different species, the spores of Bacillus horneckiae, Bacillus pumilus, and Bacillus cereus are known to possess an exosporium, while spores of $B$. subtilis do not [76,83-85]. The spore inner membrane (IM) could be involved in the resistance to several stresses, including UV radiation, charged particles, radical species, and neutral and excited atoms [86].

This work provided new insights into the resistance of extremophilic bacilli spores from hot and cold environments to He and Fe particles and how the ionizing radiation influenced their germination processes. Overall, the spores survived better following He rather than Fe ion irradiation at the maximum dose. When exposed to He irradiation, thermophilic SBP3 and T14 strains showed higher spore viability than those of psychrotolerant A34 and A43 strains. Spores from thermophilic and psychrotolerant strains principally differed in their external structures and fatty acid composition. It is known that thermophilic and psychrotolerant strains evolved structural mechanisms toward environmental multi-stresses, including the fatty acid composition of their cellular membranes and of spore IM [87]. The iso-C15 fatty acid content tends to dominate in thermophilic vegetative cells, 
as previously reported for strains SBP3 and T14 [28,30], while anteiso-C15 fatty acids dominate in psychrophilic bacterial species [88].

To compare the spore resistance to He and Fe ions of extremophilic strains with that B. subtilis 168 (Bsu), we expressed data as the dose of ionizing radiation killing $63 \%$ of the initial spore population ( $\mathrm{D}_{37}$ values) (Figure 5).


Figure 5. Spore inactivation, expressed as $D_{37}$ values (Gy) after exposure to heavy ions of (A) helium (He) and (B) iron (Fe) of environmental thermophiles Bacillus horneckiae SBP3 and Bacillus licheniformis T14, and psychrotolerants Bacillus sp. A34 and A43, with comparison to Bacillus subtilis 168 (Bsu, data from Moeller et al. [47]). Resistance of spores is expressed as averages and standard deviations $(n=3)$. For each graph, the lowercase letters above the bars denote groups with significant differences by ANOVA $(p \leq 0.05)$.

The SBP3 and T14 spore resistance to He ions was similar to spores of B. subtilis 168 (Figure 5A), which are considered powerful dosimeters for terrestrial environmental monitoring and extraterrestrial studies. Spores of T14 had the greatest resistance to Fe nuclei, which are known to present more lethal effects to spores than He nuclei [47], whereas spores of the other strains demonstrated equal resistance as B. subtilis 168 (Figure 5B).

The effects of $\mathrm{He}$ and $\mathrm{Fe}$ accelerated ions on the survived spores from thermophilic and psychrotolerant strains were investigated on structural components by using a spectroscopic technique (FTIR). Significative qualitative variations (i.e., number of peaks and their shape) in the spectra of spores were observed at increased dose of $\mathrm{He}$ and at $\mathrm{Fe} 250 \mathrm{~Gy}$ irradiation. In comparison with non-irradiated spores after He 250 Gy irradiation, we observed no significative change in all spore spectra, whereas after He $1000 \mathrm{~Gy}$ irradiation, the variations in the regions attributed to carbohydrates, lipids, and proteins (amide I and II) were evident in all the spectra, with distinctive changes for each strain. Furthermore, the FTIR spectra indicated that the irradiation with Fe 250 Gy was responsible for large injuries in all spore structures, including DNA, similarly to those observed after irradiation with He 1000 Gy.

Moeller et al. [89] reported that after He and Fe ion irradiation, the spores of B. subtilis possessed the following repair DNA mechanisms: (i) apurinic/apyrimidinic endonucleases, and (ii) non-homologous end joining repair-deficient. The $\alpha$ - $\beta$-SASP mutants were subjected to a higher rate of mutation. SASPs play essential roles in the prevention of both lethal and mutagenic damages to spore DNA induced by $\mathrm{He}$ and Fe ion irradiation [82,89]. Therefore, He and Fe particles, as producers of oxidizing agents by radiolysis of water, could be responsible of the damages in the structural spore components. However, further investigation is needed to determine the structural (i.e., protein, enzyme, or lipidic/carbohydrate coat) and molecular differences, such as the presence and efficiency of the DNA repair system involved in the spore resistance to HZE particles.

The spores from extremophilic bacteria that survived irradiation showed different germination kinetics, depending on the type/dose of irradiation and the germinant agent used. Although several 
exogenous germinants are reported to trigger germination in different species of Bacillus, different nutrient germinants are species-specific. In this study, D-glucose was the principal germinant agent for non-irradiated spores from thermophilic strains, but not for those from psychrotolerants. After exposure to He ions, the thermophilic spores germinated slower in the presence of D-glucose, probably due to the alteration of one or more germinant receptors (Ger) (e.g., GerA, YndD, or GerK), since none of the GRs can initiate an efficient germination on their own, as reported in spores from B. subtilis and B. licheniformis strain MW3 [90]. Surprisingly, glucose induced the germination of spores from psychrotolerants after exposition to He, suggesting that the radiation may affect the glucose receptor complex either directly by altering the GR structure and affinity, or indirectly by increasing the IM permeability. Presumably, the irradiation with He ions, inducing damages in the spore cortex structure of psychrotolerants, allowed for the increasing permeability of IM to glucose, as well as to amino acids L-alanine and L-valine, with the only exception being alanine for A43. Moreover, when triggered with L-alanine, the He-irradiated spores of T14 showed an increase in the germination efficiency and a decrease in lag time. This finding is corroborated by previous results indicating that the germination of B. licheniformis mutants defecting in the coat assembly increased with L-alanine [91]. Furthermore, the increasing permeability to L-alanine, as reported in germination of B. subtilis after heat exposition, was related to the upregulation of GerA and genes associated with L-alanine uptake [92]. Interestingly, all alive spores irradiated with Fe 250 Gy were unable to germinate with the agents used, indicating a block in germination, probably due to the damages of germinant receptor complex.

This study encourages future research to explore the relationship between the environmental conditions, such as temperature, and the radio-resistant properties of spores from extremophiles.

\section{Conclusions}

The HZE ions irradiation resistance of poly-extremophilic bacilli spores from hot and cold environments was investigated, resulting in modifications to structural components of spores and how those modifications influence the germination process.

Spores survived He irradiation until the highest dose, whereas they were drastically reduced at $\mathrm{Fe}$ ions, which are known to present more lethal effects to spores than He nuclei. Spores from thermophiles survived irradiation better than psychrotolerants, and T14 spores possessed the greatest resistance to Fe nuclei.

Spores that survived after irradiation showed different germination kinetics, depending on the type/dose of irradiation and the germinant agent used. After He irradiations, spores germinated more slowly in the presence of the appropriate germinant agent, as was the case for thermophiles in the presence of D-glucose. Paradoxically, after He radiation, spores' germination efficiency increased, or spores even germinated with agents that in non-irradiated conditions were not efficient. This phenomenon was most evident in psychrotolerants and can be considered as the main effect of radiation damage on the structures of spores, mainly on proteins involved in spore germination, which resulted in the increased permeability of the internal membranes and also in the alteration in the structures of the receptor complex. All spores were blocked in germination after irradiation with Fe $250 \mathrm{~Gy}$. The molecular effects of the radio-activation of spores are not as well known; therefore, further studies are needed to define the molecular mechanisms involved in the germination of our extremophiles after irradiation.

Our findings provide novel insights on the effects of HZE particles on viability and germination process of spores from poly-extremophilic bacilli. The knowledge of germinant agents and the time of out-growth could help us to determine correctly, rather than underestimate, the viability of dormant spores in different contexts, including astrobiology and the planetary protection context.

Supplementary Materials: The following are available online at http://www.mdpi.com/2075-1729/10/11/264/s1, Table S1: Germination process of non-irradiated spores and He-/Fe-irradiated spores in the presence of D-glucose (Glu), L-alanine (Ala), and L-valine (Val) as trigger compounds; the lag-time (the initial loss of the relative 
absorbance) and the efficiency of germination (loss of the relative absorbance percentage, $\mathrm{OD}_{600 \mathrm{~nm}} \%$ ) after $120 \mathrm{~min}$ of exposure to the $50 \mathrm{mM}$ germinant compound.

Author Contributions: Conceptualization, V.Z., S.G., C.G., and M.G.R.; methodology, V.Z., M.G.R., S.M., and M.T.C.; formal analysis, A.F., V.Z., M.T.C., and S.M.; investigation, V.Z., M.G.R., and M.T.C.; resources, D.F., L.M.D.P., and M.G.; data curation, C.G., S.G., and R.M.; writing-original draft preparation, V.Z., S.G., M.G.R., and C.G.; writing-review and editing, C.G., S.G., A.L.G., K.R.M., and R.M.; supervision, C.G.; funding acquisition, C.G. and M.G. All authors have read and agreed to the published version of the manuscript.

Funding: This work was funded by the FFABR Unime 2019 Research Program, supported by the University of Messina. This research was supported by grants from the PNRA (Programma Nazionale di Ricerche in Antartide) and the Italian Ministry of Education and Research (research project PNRA2016, P.I. Prof. Guglielmin).

Acknowledgments: K.R.M. and R.M. were supported by the Deutsches Zentrum für Luft- und Raumfahrt e.V. (DLR) grant FuE-Projekt "ISS LIFE" (Programm RF-FuW, Teilprogramm 475). A.F. and R.M. were supported by the MEXT grant-in-aid for Scientific Research on Innovative Areas "Living in Space" (grant numbers: 15H05935, 15K21745). A.L.G. was supported by the National Antarctic Research Program (PNRA) and the Italian Ministry of Education and Research (research projects PNRA 2013/AZ1.05 and PNRA16_00020).

Conflicts of Interest: The authors declare no conflict of interest.

\section{Abbreviations}

$\begin{array}{ll}\text { Ala } & \text { L-alanine } \\ \text { AP } & \text { Apurinic/apyrimidinic } \\ \text { CFU } & \text { Colony forming unit } \\ \text { LD } 90 & \text { Lethal dose required to kill } 90 \% \text { of the spore population } \\ \text { FTIR } & \text { Fourier transform infrared } \\ \text { GCR } & \text { Galactic cosmic radiation } \\ \text { Glu } & \text { D-glucose } \\ \text { GRs } & \text { Germinant receptors } \\ \text { HIMAC } & \text { Heavy ion medical accelerator center } \\ \text { HZE } & \text { Heavy charge energy } \\ \text { IR } & \text { Ionizing radiation } \\ \text { LET } & \text { Linear energy transfer } \\ \text { NHEJ } & \text { Non-homologous end joining } \\ \text { NIRS } & \text { National Institute for Radiological Sciences } \\ \text { OD } & \text { Optical density } \\ \text { ROS } & \text { Radical oxygen species } \\ \text { SASP } & \text { Small acid soluble proteins } \\ \text { SHV } & \text { Shallow hydrothermal vents } \\ \text { TSA } & \text { Tryptone soy agar } \\ \text { TSA1 } & \text { Tryptone soy agar with } 1 \% \mathrm{NaCl} \\ \text { Val } & \text { L-valine }\end{array}$

\section{References}

1. Fairén, A.G.; Davila, A.F.; Lim, D.; Bramall, N.; Bonaccorsi, R.; Zavaleta, J.; Uceda, E.R.; Stoker, C.; Wierzchos, J.; Dohm, J.M.; et al. Astrobiology through the Ages of Mars: The Study of Terrestrial Analogues to Understand the Habitability of Mars. Astrobiology 2010, 10, 821-843. [CrossRef] [PubMed]

2. Capece, M.C.; Clark, E.; Saleh, J.K.; Halford, D.; Heinl, N.; Hoskins, S.; Rothschild, L.J. Polyextremophiles and the constraints for terrestrial habitability. In Polyextremophiles; Seckbach, J., Oren, A., Stan-Lotter, H., Eds.; Springer: Dordrecht, The Netherlands, 2013; Volume 27, pp. 3-59.

3. Harrison, J.P.; Gheeraert, N.; Tsigelnitskiy, D.; Cockell, C.S. The limits for life under multiple extremes. Trends Microbiol. 2013, 21, 204-212. [CrossRef] [PubMed]

4. Carlson, C.; Singh, N.K.; Bibra, M.; Sani, R.K.; Venkateswaran, K. Pervasiveness of UVC254-resistant Geobacillus strains in extreme environments. Appl. Microbiol. Biotechnol. 2018, 102, 1869-1887. [CrossRef] [PubMed] 
5. Merino, N.; Aronson, H.S.; Bojanova, D.; Feyhl-Buska, J.; Wong, M.L.; Zhang, S.; Giovannelli, D. Living at the Extremes: Extremophiles and the Limits of Life in a Planetary Context. Front. Microbiol. 2019, 10, 780. [CrossRef] [PubMed]

6. Rothschild, L.J.; Mancinelli, R.L. Life in extreme environments. Nat. Cell Biol. 2001, 409, 1092-1101. [CrossRef] [PubMed]

7. Cosciotti, B.; Balbi, A.; Ceccarelli, A.; Fagliarone, C.; Mattei, E.; Lauro, S.E.; Di Paolo, F.; Pettinelli, E.; Billi, D. Survivability of Anhydrobiotic Cyanobacteria in Salty Ice: Implications for the Habitability of Icy Worlds. Life 2019, 9, 86. [CrossRef]

8. Rampelotto, P.H. Resistance of Microorganisms to Extreme Environmental Conditions and Its Contribution to Astrobiology. Sustainability 2010, 2, 1602-1623. [CrossRef]

9. Schulze-Makuch, D.; Airo, A.; Schirmack, J. The Adaptability of Life on Earth and the Diversity of Planetary Habitats. Front. Microbiol. 2017, 8, 2011. [CrossRef]

10. Horneck, G.; Walter, N.; Westall, F.; Grenfell, J.L.; Martin, W.F.; Gómez, F.; Leuko, S.; Lee, N.; Onofri, S.; Tsiganis, K.; et al. AstRoMap European Astrobiology Roadmap. Astrobiology 2016, 16, 201-243. [CrossRef]

11. Cortesão, M.; Fuchs, F.M.; Commichau, F.M.; Eichenberger, P.; Schuerger, A.C.; Nicholson, W.L.; Setlow, P.; Moeller, R. Bacillus subtilis Spore Resistance to Simulated Mars Surface Conditions. Front. Microbiol. 2019, 10, 333. [CrossRef]

12. Cavicchioli, R. Extremophiles and the Search for Extraterrestrial Life. Astrobiology 2002, 2, 281-292. [CrossRef] [PubMed]

13. Nicholson, W.L.; Schuerger, A.C.; Race, M.S. Migrating microbes and planetary protection. Trends Microbiol. 2009, 17, 389-392. [CrossRef] [PubMed]

14. Horneck, G.; Klaus, D.M.; Mancinelli, R.L. Space Microbiology. Microbiol. Mol. Biol. Rev. 2010, 74, 121-156. [CrossRef] [PubMed]

15. Parkinson, C.D.; Liang, M.-C.; Yung, Y.L.; Kirschivnk, J.L. Habitability of Enceladus: Planetary Conditions for Life. Orig. Life Evol. Biosph. 2008, 38, 355-369. [CrossRef]

16. Williams, D.M.; Knacke, R.F. Looking for planetary moons in the spectra of distant Jupiters. Astrobiology 2004, 4, 400-403. [CrossRef]

17. Taubner, R.-S.; Olsson-Francis, K.; Vance, S.D.; Ramkissoon, N.K.; Postberg, F.; De Vera, J.-P.; Antunes, A.; Casas, E.C.; Sekine, Y.; Noack, L.; et al. Experimental and Simulation Efforts in the Astrobiological Exploration of Exooceans. Sp. Sci. Rev. 2020, 216,1-41. [CrossRef]

18. Nicholson, W.L.; Munakata, N.; Horneck, G.; Melosh, H.J.; Setlow, P. Resistance of Bacillus Endospores to Extreme Terrestrial and Extraterrestrial Environments. Microbiol. Mol. Biol. Rev. 2000, 64, 548-572. [CrossRef] [PubMed]

19. Confalonieri, F.; Sommer, S. Bacterial and archaeal resistance to ionizing radiation. J. Phys. Conf. Ser. 2011, 261, 012005. [CrossRef]

20. Ranawat, P.; Rawat, S. Stress response physiology of thermophiles. Arch. Microbiol. 2017, 199, $391-414$. [CrossRef] [PubMed]

21. Ferreira, A.C.; Nobre, M.F.; Rainey, F.A.; Silva, M.T.; Wait, R.; Burghardt, J.; Chung, A.P.; Da Costa, M.S. Deinococcus geothermalis sp. nov. and Deinococcus murrayi sp. nov., Two Extremely Radiation-Resistant and Slightly Thermophilic Species from Hot Springs. Int. J. Syst. Bacteriol. 1997, 47, 939-947. [CrossRef]

22. DiRuggiero, J.; Santangelo, N.; Nackerdien, Z.; Ravel, J.; Robb, F. Repair of extensive ionizing-radiation DNA damage at 95 degrees $C$ in the hyperthermophilic archaeon Pyrococcus furiosus. J. Bacteriol. 1997, 179, 4643-4645. [CrossRef]

23. Jolivet, E.; L'Haridon, S.; Corre, E.; Forterre, P.; Prieur, D. Thermococcus gammatolerans sp. nov., a hyperthermophilic archaeon from a deep-sea hydrothermal vent that resists ionizing radiation. Int. J. Syst. Evol. Microbiol. 2003, 53, 847-851. [CrossRef] [PubMed]

24. Jolivet, E.; Corre, E.; L'Haridon, S.; Forterre, P.; Prieur, D. Thermococcus marinus sp. nov. and Thermococcus radiotolerans sp. nov., two hyperthermophilic archaea from deep-sea hydrothermal vents that resist ionizing radiation. Extremophiles 2004, 8, 219-227. [CrossRef] [PubMed]

25. Setlow, P. Spores of Bacillus subtilis: Their resistance to and killing by radiation, heat and chemicals. J. Appl. Microbiol. 2006, 101, 514-525. [CrossRef] [PubMed] 
26. Caccamo, D.; Gugliandolo, C.; Stackebrandt, E.; Maugeri, T.L. Bacillus vulcani sp. nov., a novel thermophilic species isolated from a shallow marine hydrothermal vent. Int. J. Syst. Evol. Microbiol. 2000, 50, $2009-2012$. [CrossRef] [PubMed]

27. Gugliandolo, C.; Lentini, V.; Spanò, A.; Maugeri, T. New bacilli from shallow hydrothermal vents of Panarea Island (Italy) and their biotechnological potential. J. Appl. Microbiol. 2012, 112, 1102-1112. [CrossRef]

28. Spanò, A.; Gugliandolo, C.; Lentini, V.; Maugeri, T.L.; Anzelmo, G.; Poli, A.; Nicolaus, B. A Novel EPS-Producing Strain of Bacillus licheniformis Isolated from a Shallow Vent Off Panarea Island (Italy). Curr. Microbiol. 2013, 67, 21-29. [CrossRef]

29. Spanò, A.; Laganà, P.; Visalli, G.; Maugeri, T.L.; Gugliandolo, C. In Vitro Antibiofilm Activity of an Exopolysaccharide from the Marine Thermophilic Bacillus licheniformis T14. Curr. Microbiol. 2016, 72, 518-528. [CrossRef]

30. Zammuto, V.; Laue, M.; Fiebrandt, M.; Stapelmann, K.; Ulrich, N.J.; Maugeri, T.L.; Pukall, R.; Gugliandolo, C.; Moeller, R. Comparing Spore Resistance of Bacillus Strains Isolated from Hydrothermal Vents and Spacecraft Assembly Facilities to Environmental Stressors and Decontamination Treatments. Astrobiology 2018, 18, 1425-1434. [CrossRef]

31. Zammuto, V.; Conte, A.; Michaud, L.; Papale, M.; Guglielmin, M.; Romano, I.; Vizzini, S.; Lo Giudice, A.; Gugliandolo, C. Extremophiles from cold and hot environments resistant to ultraviolet radiation (UV-C) simulating space environment. J. Biol. Res. 2016, 86, 17.

32. Zammuto, V.; Gugliandolo, C. Resistance to high temperatures of spores from bacilli of shallow hydrothermal vent origins. AAPP Atti della Accademia Peloritana dei Pericolant Classe di Scienze Fisiche, Matematiche e Naturali 2019, 97, 28.

33. Setlow, P. Observations on research with spores of Bacillales and Clostridiales species. J. Appl. Microbiol. 2018, 126, 348-358. [CrossRef]

34. Reineke, K.; Ellinger, N.; Berger, D.; Baier, D.; Mathys, A.; Setlow, P.; Knorr, D. Structural analysis of high pressure treated Bacillus subtilis spores. Innov. Food Sci. Emerg. Technol. 2013, 17, 43-53. [CrossRef]

35. Nagler, K.; Julius, C.; Moeller, R. Germination of Spores of Astrobiologically RelevantBacillusSpecies in High-Salinity Environments. Astrobiology 2016, 16, 500-512. [CrossRef]

36. He, L.; Chen, Z.; Wang, S.; Wu, M.; Setlow, P.; Li, Y.-Q. Germination, Outgrowth, and Vegetative-Growth Kinetics of Dry-Heat-Treated Individual Spores ofBacillusSpecies. Appl. Environ. Microbiol. 2018, 84, e02618-17. [CrossRef]

37. Atluri, S.; Ragkousi, K.; Cortezzo, D.E.; Setlow, P. Cooperativity between Different Nutrient Receptors in Germination of Spores of Bacillus subtilis and Reduction of This Cooperativity by Alterations in the GerB Receptor. J. Bacteriol. 2006, 188, 28-36. [CrossRef] [PubMed]

38. Webb, K.M.; DiRuggiero, J. Role of Mn2+ and Compatible Solutes in the Radiation Resistance of Thermophilic Bacteria and Archaea. Archaea 2012, 2012,1-11. [CrossRef]

39. Edwards, H.; Moeller, R.; Jorge-Villar, S.E.; Horneck, G.; Stackebrandt, E. Raman spectroscopic study of the photoprotection of extremophilic microbes against ultraviolet radiation. Int. J. Astrobiol. 2006, 5, 313-318. [CrossRef]

40. Dartnell, L. Ionizing Radiation and Life. Astrobiology 2011, 11, 551-582. [CrossRef]

41. Ferrari, F.; Szuszkiewicz, E. Cosmic Rays: A Review for Astrobiologists. Astrobiology 2009, 9, 413-436. [CrossRef]

42. Durante, M.; Cucinotta, F.A. Heavy ion carcinogenesis and human space exploration. Nat. Rev. Cancer 2008, 8, 465-472. [CrossRef]

43. De Vera, J.-P.; Alawi, M.; Backhaus, T.; Baqué, M.; Billi, D.; Böttger, U.; Berger, T.; Bohmeier, M.; Cockell, C.; DeMets, R.; et al. Limits of Life and the Habitability of Mars: The ESA Space Experiment BIOMEX on the ISS. Astrobiology 2019, 19, 145-157. [CrossRef] [PubMed]

44. Takahashi, A.; Ikeda, H.; Yoshida, Y. Role of High-Linear Energy Transfer Radiobiology in Space Radiation Exposure Risks. Int. J. Part. Ther. 2018, 5, 151-159. [CrossRef] [PubMed]

45. Moeller, R.; Raguse, M.; Leuko, S.; Berger, T.; Hellweg, C.E.; Fujimori, A.; Okayasu, R.; Horneck, G.; STARLIFE Research Group. STARLIFE-An International Campaign to Study the Role of Galactic Cosmic Radiation in Astrobiological Model Systems. Astrobiology 2017, 17, 101-109. [CrossRef] [PubMed] 
46. Moeller, R.; Setlow, P.; Horneck, G.; Berger, T.; Reitz, G.; Rettberg, P.; Doherty, A.J.; Okayasu, R.; Nicholson, W.L. Roles of the Major, Small, Acid-Soluble Spore Proteins and Spore-Specific and Universal DNA Repair Mechanisms in Resistance of Bacillus subtilis Spores to Ionizing Radiation from X Rays and High-Energy Charged-Particle Bombardment. J. Bacteriol. 2007, 190, 1134-1140. [CrossRef]

47. Moeller, R.; Reitz, G.; Berger, T.; Okayasu, R.; Nicholson, W.L.; Horneck, G. Astrobiological Aspects of the Mutagenesis of Cosmic Radiation on Bacterial Spores. Astrobiology 2010, 10, 509-521. [CrossRef]

48. Moeller, R.; Schuerger, A.C.; Reitz, G.; Nicholson, W.L. Protective Role of Spore Structural Components in Determining Bacillus subtilis Spore Resistance to Simulated Mars Surface Conditions. Appl. Environ. Microbiol. 2012, 78, 8849-8853. [CrossRef]

49. Papale, M.; Conte, A.; Mikkonen, A.; Michaud, L.; La Ferla, R.; Azzaro, M.; Caruso, G.; Paranhos, R.; Anderson, S.C.; Maimone, G.; et al. Prokaryotic assemblages within permafrost active layer at Edmonson Point (Northern Victoria Land, Antarctica). Soil Biol. Biochem. 2018, 123, 165-179. [CrossRef]

50. Nagler, K.; Setlow, P.; Li, Y.-Q.; Moeller, R. High Salinity Alters the Germination Behavior of Bacillus subtilis Spores with Nutrient and Nonnutrient Germinants. Appl. Environ. Microbiol. 2013, 80, 1314-1321. [CrossRef]

51. Okayasu, R.; Okada, M.; Okabe, A.; Noguchi, M.; Takakura, K.; Takahashi, S. Repair of DNA Damage Induced by Accelerated Heavy Ions in Mammalian Cells Proficient and Deficient in the Non-homologous End-Joining Pathway. Radiat. Res. 2006, 165, 59-67. [CrossRef]

52. Orsini, F.; Ami, D.; Villa, A.M.; Sala, G.; Bellotti, M.G.; Doglia, S.M. FT-IR microspectroscopy for microbiological studies. J. Microbiol. Methods 2000, 42, 17-27. [CrossRef]

53. Caccamo, M.T.; Gugliandolo, C.; Zammuto, V.; Magazù, S. Thermal properties of an exopolysaccharide produced by a marine thermotolerant Bacillus licheniformis by ATR-FTIR spectroscopy. Int. J. Biol. Macromol. 2019, 145, 77-83. [CrossRef] [PubMed]

54. Vongsvivut, J.; Heraud, P.; Zhang, W.; Kralovec, J.A.; McNaughton, D.; Barrow, C.J. Rapid Determination of Protein Contents in Microencapsulated Fish Oil Supplements by ATR-FTIR Spectroscopy and Partial Least Square Regression (PLSR) Analysis. Food Bioprocess Technol. 2013, 7, 265-277. [CrossRef]

55. Guillén, M.D.; Cabo, N. Characterization of edible oils and lard by Fourier transform infrared spectroscopy. Relationships between composition and frequency of concrete bands in the fingerprint region. J. Am. Oil Chem. Soc. 1997, 74, 1281-1286. [CrossRef]

56. Filip, Z.; Herrmann, S.; Kubát, J. FT-IR spectroscopic characteristics of differently cultivated Bacillus subtilis. Microbiol. Res. 2004, 159, 257-262. [CrossRef]

57. Böcker, U.; Kristoffersen, K.A.; Lindberg, D.; Afseth, N.K. Fourier-transform infrared spectroscopy for characterization of protein chain reductions in enzymatic reactions. Analyst 2017, 142, 2812-2818. [CrossRef]

58. Serrano, V.; Liu, W.-G.; Franzen, S. An Infrared Spectroscopic Study of the Conformational Transition of Elastin-Like Polypeptides. Biophys. J. 2007, 93, 2429-2435. [CrossRef]

59. Perkins, D.L.; Lovell, C.R.; Bronk, B.V.; Setlow, B.; Setlow, P.; Myrick, M.L. Fourier transform infrared reflectance micro-spectroscopy study of Bacillus subtilis engineered without dipicolinic acid: The contribution of calcium dipicolinate to the mid-infrared absorbance of Bacillus subtilis endospores. Appl. Spectrosc. 2005, 59, 893-896. [CrossRef]

60. Bizani, D.; Motta, A.S.; Morrissy, J.A.C.; Terra, R.M.S.; Souto, A.A.; Brandelli, A. Antibacterial activity of cerein 8A, a bacteriocin-like peptide produced by Bacillus cereus. Int. Microbiol. 2005, 8, 125-131.

61. Rohman, A.; Man, Y.C. Fourier transform infrared (FTIR) spectroscopy for analysis of extra virgin olive oil adulterated with palm oil. Food Res. Int. 2010, 43, 886-892. [CrossRef]

62. Zelig, U.; Mordechai, S.; Shubinsky, G.; Sahu, R.K.; Huleihel, M.; Leibovitz, E.; Nathan, I.; Kapelushnik, J. Pre-screening and follow-up of childhood acute leukemia using biochemical infrared analysis of peripheral blood mononuclear cells. Biochim. Biophys. Acta (BBA) Gen. Subj. 2011, 1810, 827-835. [CrossRef]

63. Johnson, P.V.; Hodyss, R.; Chernow, V.F.; Lipscomb, D.M.; Goguen, J.D. Ultraviolet photolysis of amino acids on the surface of icy Solar System bodies. Icarus 2012, 221, 800-805. [CrossRef]

64. McKenna-Lawlor, S.; Goncalves, P.; Keating, A.; Reitz, G.; Matthiä, D. Overview of energetic particle hazards during prospective manned missions to Mars. Planet. Sp. Sci. 2012, 63, 123-132. [CrossRef]

65. Tsou, P.; Brownlee, D.E.; McKay, C.P.; Anbar, A.D.; Yano, H.; Altwegg, K.; Beegle, L.W.; Dissly, R.; Strange, N.J.; Kanik, I. LIFE: Life Investigation For EnceladusA Sample Return Mission Concept in Search for Evidence of Life. Astrobiology 2012, 12, 730-742. [CrossRef] 
66. Roth, L.; Saur, J.; Retherford, K.D.; Strobel, D.; Feldman, P.D.; McGrath, M.A.; Nimmo, F. Transient Water Vapor at Europa's South Pole. Science 2013, 343, 171-174. [CrossRef]

67. Grießmeier, J.-M.; Zarka, P.; Spreeuw, H. Predicting low-frequency radio fluxes of known extrasolar planets. Astron. Astrophys. 2007, 475, 359-368. [CrossRef]

68. Medvedev, M.V.; Melott, A.L. Do Extragalactic Cosmic Rays Induce Cycles in Fossil Diversity? Astrophys. J. 2007, 664, 879-889. [CrossRef]

69. Kiefer, J. (Ed.) Elements of photo-and radiation chemistry. In Biological Radiation Effects; Springer: Berlin, Germany, 1990; pp. 88-103.

70. Horneck, G. Space Radiation Biology. In Biology in Space and Life on Earth: Effects of Spaceflight on Biological Systems; Brinckmann, E., von Friedeburg, C., Eds.; Wiley-VCH: Berlin, Germany, 2007; pp. 243-273.

71. Dianov, G.L.; O'Neill, P.; Goodhead, D.T. Securing genome stability by orchestrating DNA repair: Removal of radiation-induced clustered lesions in DNA. BioEssays 2001, 23, 745-749. [CrossRef]

72. Nicastro, A.J.; Vreeland, R.H.; Rosenzweig, W.D. Limits imposed by ionizing radiation on the long-term survival of trapped bacterial spores: Beta radiation. Int. J. Radiat. Biol. 2002, 78, 891-901. [CrossRef]

73. Setlow, B.; Cowan, A.E.; Setlow, P. Germination of spores of Bacillus subtilis with dodecylamine. J. Appl. Microbiol. 2003, 95, 637-648. [CrossRef]

74. Zhang, P.; Liang, J.; Yi, X.; Setlow, P.; Li, Y.-Q. Monitoring of Commitment, Blocking, and Continuation of Nutrient Germination of Individual Bacillus subtilis Spores. J. Bacteriol. 2014, 196, 2443-2454. [CrossRef]

75. McKay, C.P.; Anbar, A.D.; Porco, C.; Tsou, P. Follow the Plume: The Habitability of Enceladus. Astrobiology 2014, 14, 352-355. [CrossRef]

76. Driks, A. Maximum shields: The assembly and function of the bacterial spore coat. Trends Microbiol. 2002, 10, 251-254. [CrossRef]

77. Hullo, M.-F.; Moszer, I.; Danchin, A.; Martin-Verstraete, I. CotA of Bacillus subtilis is a Copper-Dependent Laccase. J. Bacteriol. 2001, 183, 5426-5430. [CrossRef]

78. Moeller, R.; Setlow, P.; Reitz, G.; Nicholson, W.L. Roles of Small, Acid-Soluble Spore Proteins and Core Water Content in Survival of Bacillus subtilis Spores Exposed to Environmental Solar UV Radiation. Appl. Environ. Microbiol. 2009, 75, 5202-5208. [CrossRef]

79. Paidhungat, M.; Setlow, P. Role of Ger Proteins in Nutrient and Nonnutrient Triggering of Spore Germination in Bacillus subtilis. J. Bacteriol. 2000, 182, 2513-2519. [CrossRef]

80. Slieman, T.A.; Nicholson, W.L. Role of Dipicolinic Acid in Survival ofBacillus subtilis Spores Exposed to Artificial and Solar UV Radiation. Appl. Environ. Microbiol. 2001, 67, 1274-1279. [CrossRef]

81. Setlow, P. I will survive: DNA protection in bacterial spores. Trends Microbiol. 2007, 15, 172-180. [CrossRef]

82. Moeller, R.; Reitz, G.; Li, Z.; Klein, S.; Nicholson, W.L. Multifactorial Resistance ofBacillus subtilisSpores to High-Energy Proton Radiation: Role of Spore Structural Components and the Homologous Recombination and Non-Homologous End Joining DNA Repair Pathways. Astrobiology 2012, 12, 1069-1077. [CrossRef] [PubMed]

83. Link, L.; Sawyer, J.; Venkateswaran, K.; Nicholson, W. Extreme Spore UV Resistance of Bacillus pumilus Isolates Obtained from an Ultraclean Spacecraft Assembly Facility. Microb. Ecol. 2003, 47, 159-163. [CrossRef]

84. Redmond, C.; Baillie, L.W.J.; Hibbs, S.; Moir, A.J.G.; Moir, A. Identification of proteins in the exosporium of Bacillus anthracis. Microbiology 2004, 150, 355-363. [CrossRef] [PubMed]

85. Alimova, A.; Katz, A.; Gottlieb, P.; Alfano, R.R. Proteins and dipicolinic acid released during heat shock activation of Bacillus subtilis spores probed by optical spectroscopy. Appl. Opt. 2006, 45, 445-450. [CrossRef] [PubMed]

86. Raguse, M.; Fiebrandt, M.; Denis, B.; Stapelmann, K.; Eichenberger, P.; Driks, A.; Eaton, P.; Awakowicz, P.; Möller, R. Understanding of the importance of the spore coat structure and pigmentation in theBacillus subtilisspore resistance to low-pressure plasma sterilization. J. Phys. D Appl. Phys. 2016, 49, 285401. [CrossRef]

87. Griffiths, K.; Setlow, P. Effects of modification of membrane lipid composition onBacillus subtilissporulation and spore properties. J. Appl. Microbiol. 2009, 106, 2064-2078. [CrossRef]

88. Nicolaus, B.; Panico, A.; Manca, M.C.; Lama, L.; Gambacorta, A.; Maugeri, T.; Gugliandolo, C.; Caccamo, D. A Thermophilic Bacillus Isolated From an Eolian Shallow Hydrothermal Vent Able to Produce Exopolysaccharides. Syst. Appl. Microbiol. 2000, 23, 426-432. [CrossRef] 
89. Moeller, R.; Raguse, M.; Reitz, G.; Okayasu, R.; Li, Z.; Klein, S.; Setlow, P.; Nicholson, W.L. Resistance of Bacillus subtilis Spore DNA to Lethal Ionizing Radiation Damage Relies Primarily on Spore Core Components and DNA Repair, with Minor Effects of Oxygen Radical Detoxification. Appl. Environ. Microbiol. 2013, 80, 104-109. [CrossRef] [PubMed]

90. Borch-Pedersen, K.; Lindbäck, T.; Madslien, E.H.; Kidd, S.W.; O'Sullivan, K.; Granum, P.E.; Aspholm, M. The Cooperative and Interdependent Roles of GerA, GerK, and Ynd in Germination of Bacillus licheniformis Spores. Appl. Environ. Microbiol. 2016, 82, 4279-4287. [CrossRef]

91. Løvdal, I.S.; From, C.; Madslien, E.H.; Romundset, K.C.S.; Klufterud, E.; Rosnes, J.T.; Granum, P.E. Role of the gerA operon in L-alanine germination of Bacillus licheniformis spores. BMC Microbiol. 2012, 12, 34. [CrossRef]

92. Feavers, I.M.; Foulkes, J.; Setlow, B.; Sun, D.; Nicholson, W.; Setlow, P.; Moir, A. The regulation of transcription of the gerA spore germination operon of Bacillus subtilis. Mol. Microbiol. 1990, 4, 275-282. [CrossRef]

Publisher's Note: MDPI stays neutral with regard to jurisdictional claims in published maps and institutional affiliations.

(C) 2020 by the authors. Licensee MDPI, Basel, Switzerland. This article is an open access article distributed under the terms and conditions of the Creative Commons Attribution (CC BY) license (http://creativecommons.org/licenses/by/4.0/). 